\title{
Faktor-Faktor yang Mempengaruhi Akses Kesehatan
}

\author{
Factors Affecting Health Access
}

\author{
Raditiya Firda Maulany(1), Ragil Setia Dianingati(2), Eva Annisaa'(3) \\ (1)(2)(3)Program Studi Farmasi , Universitas Diponegoro Semarang \\ e-mail : rsdianingati@lecturer.undip.ac.id
}

\begin{abstract}
ABSTRAK
Akses kesehatan merupakan bentuk dari pelayanan kesehatan yang dapat dijangkau oleh masyarakat. Akses kesehatan seringkali hanya dilihat dari sudut pandang penyedia layanan, sementara akses dari sisi masyarakat sebagai pengguna kurang terperhatikan. Penelitian tentang akses pelayanan kesehatan dari perspektif pengguna dirasakan masih sangat kurang. Penelitian tentang akses pelayanan kesehatan dari sisi pengguna masih kurang. Peningkatan kualitas pelayanan kesehatan dari segi akses memerlukan perspektif yang komprehensif dari dua sisi yang berbeda. Tujuan dari review artikel ini adalah untuk menganalisis faktor-faktor yang mempengaruhi masyarakat dalam mengakses fasilitas kesehatan. Desain metode yang digunakan merupakan review artikel, hasil data yang diperoleh berdasarkan kumpulan dari penelitian terkait. Metode pecarian sumber dilakukan dengan menggunakan kata kunci "akses kesehatan", "pelayanan kesehatan" dan "fasilitas kesehatan" yang dilakukan pada bulan Desember 2020. Kriteria inklusi artikel yang digunakan yaitu artikel tahun 2011-2020 dan bertujuan mengetahui faktor-faktor yang mempengaruhi akses fasilitas kesehatan. Kriteria eksklusi penelitian ini yaitu review artikel, artikel yang tidak menyediakan full text atau hanya menyediakan abstrak dan hasil skripsi, tesis, disertasi. Pencarian dari database menghasilkan 73 artikel, dimana hanya terdapat 5 artikel yang memenuhi kriteria inklusi. Hasil review artikel menunjukkan bahwa faktor-faktor yang mempengaruhi akses kesehatan antara lain jenis kelamin, waktu tempuh, lokasi tempat tinggal, biaya transportasi, persepsi masyarakat tentang kesehatan, pendapatan, pendidikan, pengetahuan.
\end{abstract}

Kata kunci : Akses, Pelayanan Kesehatan, Fasilitas Kesehatan

\begin{abstract}
Health access is a form of health services that can be reached by the community. Access to health is often only seen from the point of view of service providers, while access from the community side as users is less noticed. Research on access to health services from the user's perspective is still lacking. Research on access to health services from the user's point of view is still lacking. Improving the quality of health services in terms of access requires a comprehensive perspective from two different sides. The purpose of this review article is to analyze the factors that influence people's access to health facilities. The design method used is a review of articles, the results of the data obtained are based on a collection of related research. The source search method was carried out using the keywords "health access", "health services" and "health facilities" which was carried out in December 2020. The article inclusion criteria used were articles in 2011-2020 and aimed to determine the factors that influence access to facilities. health. The exclusion criteria for this research are article reviews, articles that do not provide full text or only provide abstracts and the results of theses, theses, and dissertations. A search of the database yielded 73 articles, of which only 5 met the inclusion criteria. The results of the article review show that the factors that influence access to health include gender, travel time, location of residence,
\end{abstract}


transportation costs, public perceptions of health, income, education, and knowledge.

Keywords: Access, Health Services, Health Facilities.

\section{PENDAHULUAN}

Akses menurut Kamus Besar Bahasa Indonesia (KBBI) memiliki arti jalan masuk. Sehingga secara umum akses pelayanan kesehatan dapat diartikan sebagai suatu bentuk pelayanan kesehatan dengan berbagai macam jenis pelayanannya yang dapat dijangkau oleh masyarakat (Badan Pengembangan dan Pembinaan Bahasa, 2016) Akses dibagi menjadi tiga aspek, yaitu akses geografis, ekonomi dan sosial. Akses geografis didefinisikan sebagai kemudahan akses terhadap pelayanan kesehatan yang diukur dari jarak, waktu tempuh, jenis transpotasi, dan prasarana jalan. Akses ekonomi menekankan pada kemampuan masyarakat untuk mengalokasikan sumber daya keuangan untuk mengakses layanan kesehatan. Sedangkan pendekatan sosial lebih kepada komunikasi, budaya, keramahan dan kepuasan pelayanan (Laksono, 2016). Untuk meningkatkan kondisi kesehatan masyarakat, Kementerian Kesehatan meningkatkan akses masyarakat terhadap pelayanan kesehatan yang berkualitas. Namun diakui pembangunan kesehatan masih menghadapi berbagai tantangan, seperti terjadinya kesenjangan antara status kesehatan masyarakat, status sosial dan ekonomi antar daerah, munculnya berbagai masalah/penyakit kesehatan baru atau penyakit menular yang berulang (Kemenkes, 2013). Berdasarkan profil kesehatan Indonesia tahun 2010, sarana pelayanan kesehatan Indonesia adalah 329.460 unit, terdiri dari 1.632 rumah sakit dan 9.005 unit Puskesmas. 2.920 unit menurut Puskesmas Pembantu (Pustu). Mengingat jumlah fasilitas kesehatan yang ada sebanyak 23.049 unit dan 318.823 unit fasilitas kesehatan lainnya yang terdiri dari Posyandu dan Poskesdes. Banyaknya fasilitas kesehatan yang tersedia, menimbulkan pertanyaan apakah mereka mampu memberikan pelayanan medis terbaik dan dapat diakses semua lapisan masyarakat.
Dalam hal ini, pemerintah, Kementerian Kesehatan dan pemangku kepentingan lainnya dituntut untuk menyediakan fasilitas kesehatan yang seragam di seluruh Indonesia. Dengan demikian, setiap warga dapat mengakses pelayanan kesehatan dengan biaya lebih murah dan lebih dekat dengan tempat tinggal masyarakat (Kemenkes, 2010). Akses terhadap layanan kesehatan seringkali hanya dilihat dari sudut pandang penyedia layanan, sedangkan akses dari masyarakat oleh pengguna kurang diperhatikan. Penelitian tentang akses pelayanan kesehatan dari sisi pengguna masih kurang. Peningkatan kualitas pelayanan kesehatan dari segi aksesibilitas memerlukan perspektif yang komprehensif dari dua sisi yang berbeda (Leach et al., 2018). Berdasarkan uraian di atas perlu dilakukan analisis faktorfaktor yang mempengaruhi masyarakat dalam mengakses fasilitas kesehatan. Artikel ini memberikan ulasan mengenai faktor-faktor yang mempengaruhi akses kesehatan di masyarakat melalui penelitian terdahulu atau mengambil data sekunder dari berbagai sumber.

\section{METODE PENELITIAN}

Desain penelitian ini merupakan review artikel yang didapatkan dari kumpulan penelitian terkait. Metode pecarian sumber dilakukan dengan menggunakan kata kunci "akses kesehatan", "pelayanan kesehatan" dan "fasilitas kesehatan" yang dilakukan pada bulan Desember 2020. Pencarian artikel diakses melalui beberapa sumber yaitu Google Scholar, pubmed dan NCBI. Kriteria inklusi artikel yang digunakan yaitu artikel tahun 2011-2020 dan bertujuan mengetahui faktor-faktor yang mempengaruhi akses fasilitas kesehatan. Kriteria eksklusi penelitian ini yaitu review artikel, artikel yang tidak menyediakan full text atau hanya menyediakan abstrak dan hasil skripsi, tesis, disertasi. Pencarian dari database 
menghasilkan 73 artikel, dimana hanya terdapat 5 artikel yang memenuhi kriteria inklusi.

\section{HASIL DAN PEMBAHASAN \\ Hasil}

Fasilitas pelayanan kesehatan adalah tempat yang digunakan untuk menyelenggarakan upaya pelayanan kesehatan, baik promosi, pencegahan, penyembuhan, maupun rehabilitasi, yang dilaksanakan oleh pemerintah, pemerintah daerah, dan/atau masyarakat. Pelayanan promosi dan pencegahan kesehatan bertujuan untuk

\section{Tabel 1. Review Artikel}

memberikan informasi kepada masyarakat tentang pola hidup sehat dan mencegah timbulnya masalah atau penyakit kesehatan masyarakat. Sedangkan pelayanan kesehatan kuratif dan rehabilitatif difokuskan pada penyembuhan dan pengobatan penyakit serta mengembalikan yang telah menderita penyakit tersebut kembali ke masyarakat. Berikut merupakan hasil review dari faktor-faktor yang mempengaruhi akses kesehatan.

\begin{tabular}{|c|c|c|c|c|}
\hline Penulis & Judul & $\begin{array}{l}\text { Rancangan } \\
\text { Penelitian }\end{array}$ & Instrumen & Hasil \\
\hline $\begin{array}{l}\text { Husnul } \\
\text { Khatimah } \\
\text { et al., } 2019\end{array}$ & $\begin{array}{l}\text { Faktor-Faktor } \\
\text { yang } \\
\text { Berhubungan } \\
\text { dengan Akses } \\
\text { Layanan } \\
\text { Kesehatan } \\
\text { Masyarakat } \\
\text { Adat di } \\
\text { Kabupaten } \\
\text { Jayapura } \\
\text { Provinsi } \\
\text { Papua Tahun } \\
2018\end{array}$ & $\begin{array}{c}\text { Cross } \\
\text { sectional }\end{array}$ & Kuisoner & $\begin{array}{l}\text { Fasilitas kesehatan dengan waktu } \\
\text { tempuh kurang dari atau sama dengan } \\
\text { tiga puluh menit lebih sering diakses } \\
\text { oleh masyarakat adat dibanding diatas } \\
\text { tiga puluh menit. Masyarakat adat } \\
\text { yang memiliki kendaraan pribadi } \\
\text { lebih sering mengakses layanan } \\
\text { kesehatan dibanding yang tidak } \\
\text { memiliki atau menggunakan } \\
\text { transportasi umum. Masyarakat adat } \\
\text { yang tinggal di kota lebih sering } \\
\text { menggakses layanan kesehatan } \\
\text { dibanding di desa. }\end{array}$ \\
\hline $\begin{array}{l}\text { Muh. } \\
\text { Ryman } \\
\text { Napirah et } \\
\text { al., } 2016\end{array}$ & $\begin{array}{l}\text { Faktor-Faktor } \\
\text { yang } \\
\text { Berhubungan } \\
\text { dengan } \\
\text { Pemanfaatan } \\
\text { Pelayanan } \\
\text { Kesehatan di } \\
\text { Wilayah Kerja } \\
\text { Puskesmas } \\
\text { Tambarana } \\
\text { Kecamatan } \\
\text { Poso Pesisir }\end{array}$ & $\begin{array}{c}\text { Cross } \\
\text { sectional }\end{array}$ & Kuisoner & $\begin{array}{l}\text { Terdapat hubungan persepsi } \\
\text { masyarakat tentang kesehatan dengan } \\
\text { pemanfaatan pelayanan kesehatan, ada } \\
\text { hubungan antara persepsi masyarakat } \\
\text { tentang kualitas pelayanan dengan } \\
\text { pemanfaatan pelayanan kesehatan, } \\
\text { ada hubungan antara pendapatan } \\
\text { keluarga dengan, ada hubungan antara } \\
\text { tingkat pendidikan dengan } \\
\text { pemanfaatan pelayanan kesehatan. }\end{array}$ \\
\hline
\end{tabular}




\begin{tabular}{|c|c|c|c|c|}
\hline (1) & & & \multicolumn{2}{|c|}{$\begin{array}{l}\text { Indonesian Journal of Pharmacy and Natural Product } \\
\qquad \begin{array}{r}\text { http:/jurnal.unw.ac.id/index.php/ijpnp } \\
\text { Volume 04, Nomor 02, September, } 2021 \\
p-I S S N: 2656-3215 \\
\text { e-ISSN : } 2615-6903\end{array}\end{array}$} \\
\hline Penulis & Judul & $\begin{array}{l}\text { Rancangan } \\
\text { Penelitian }\end{array}$ & Instrumen & Hasil \\
\hline $\begin{array}{l}\text { Karman et } \\
\text { al., } 2016\end{array}$ & $\begin{array}{l}\text { Faktor-Faktor } \\
\text { Yang } \\
\text { Berhubungan } \\
\text { Dengan } \\
\text { Pemanfaatan } \\
\text { Pelayanan } \\
\text { Kesehatan Bagi } \\
\text { Masyarakat } \\
\text { Pesisir Di Desa } \\
\text { Bungin } \\
\text { Permai } \\
\text { Kecamatan } \\
\text { Tinanggea } \\
\text { kabupaten } \\
\text { Konawe } \\
\text { Selatan Tahun } \\
\text { 2016 }\end{array}$ & $\begin{array}{c}\text { Cross } \\
\text { sectional }\end{array}$ & Kuisoner & 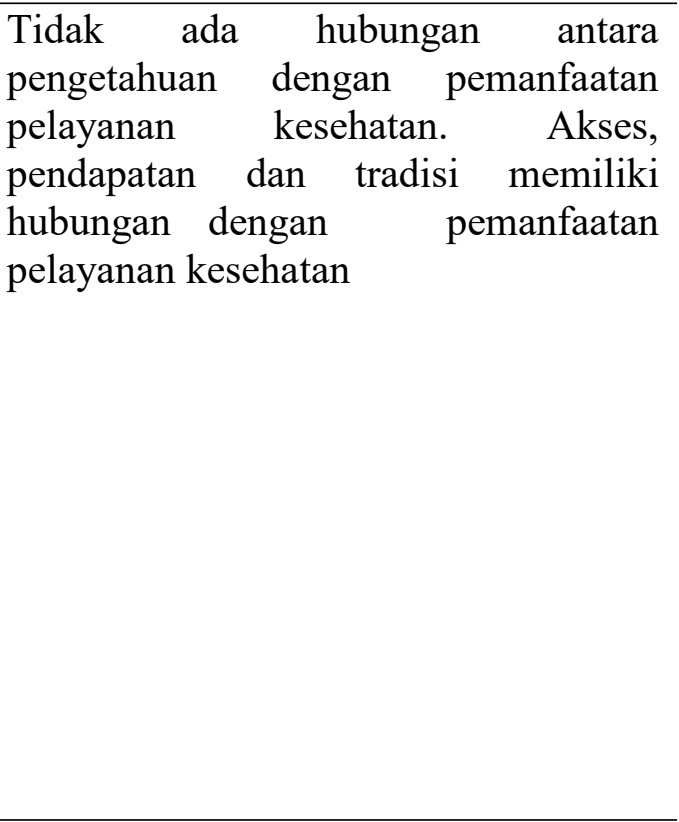 \\
\hline $\begin{array}{l}\text { Otieno } \\
\text { Stephen } \\
\text { Odiwuor et } \\
\text { al., } 2014\end{array}$ & $\begin{array}{l}\text { Factors } \\
\text { Influencing } \\
\text { Utilization of } \\
\text { Health Services } \\
\text { in Kenya: The } \\
\text { Case of Homa } \\
\text { Bay County }\end{array}$ & $\begin{array}{c}\text { Cross } \\
\text { sectional }\end{array}$ & $\begin{array}{l}\text { Wawancara } \\
\text { dan } \\
\text { Kuisoner }\end{array}$ & $\begin{array}{l}\text { Terdapat hubungan antara pendapatan, } \\
\text { sarana transportasi, dan jarak tempat } \\
\text { tinggal dengan akses masyarakat ke } \\
\text { fasilitas kesehatan }\end{array}$ \\
\hline $\begin{array}{l}\text { VY Adam, } \\
2014\end{array}$ & $\begin{array}{l}\text { Perceptions } \\
\text { and Factors } \\
\text { Affeccting } \\
\text { Utilization of } \\
\text { Health } \\
\text { Service in a } \\
\text { Rural } \\
\text { Community in } \\
\text { Southern } \\
\text { Nigeria }\end{array}$ & $\begin{array}{c}\text { Cross } \\
\text { sectional }\end{array}$ & $\begin{array}{l}\text { Wawancara } \\
\text { dan } \\
\text { kuisoner }\end{array}$ & $\begin{array}{l}\text { Tidak terdapat hubungan antara jenis } \\
\text { kelamin dan pendapatan dengan akses } \\
\text { pelayanan kesehatan. }\end{array}$ \\
\hline
\end{tabular}

\section{Pembahasan}


Berdasarkan review artikel yang telah dilakukan akses kesehatan dipengaruhi oleh beberapa faktor, antara lain:

Faktor jenis kelamin. Jenis kelamin bepengaruh pada akses pelayanan kesehatan dimana perempuan lebih sering mengakses pelayanan kesehatan dibandingkan lakilaki(Khatimah et al., 2019). Dibandingkan dengan laki-laki, perempuan melaporkan morbiditas yang lebih tinggi dan penggunaan layanan kesehatan yang lebih besar (Men et al., 2012). Namun,, pada penelitian yang dilakukan di Nigeria laki-laki mengakses pelayanan kesehatan sedikit lebih banyak daripada perempuan, namun secara statistik tidak ada perbedaan yang signifikan antara jenis kelamin dan akses pelayanan kesehatan. Hal ini dikarenakan kemiskinan yang lebih tinggi di kalangan perempuan. Alasan lain karena kepercayaan dan praktik sosial budaya di Nigeria, yang membatasi kemampuan perempuan untuk mengambil keputusan tentang hidup mereka, termasuk keputusan untuk mencari perawatan kesehatan yang tepat (Adam \& Awunor, 2014)

Faktor waktu tempuh. Waktu tempuh yang lama menghambat aksesibilitas ke fasilitas kesehatan. Waktu tempuh menuju puskesmas lebih dari 30 menit menurunkan tingkat utilisasi puskesmas. Waktu tempuh mempunyai pengaruh dengan akses ke fasilitas kesehatan dimana waktu tempuh fasilitas kesehatan kurang dari atau sama dengan 30 menit lebih sering di akses dibanding waktu tempuh fasilitas kesehatan lebih dari 30 menit (Khatimah et al., 2019). Waktu tempuh lebih dari 60 menit hanya mempunyai kunjungan ke fasilitas kesehatan sebesar 8,8\% dibandingkan waktu tempuh yang kurang dari 30 menit memanfaatkan fasilitas kesehatan sebesar 64,94\% (Levesque et al., 2013).

Faktor biaya ransportasi dan lokasi tempat tinggal. Transportasi menjadi salah satu kendala bagi masyarakat dalam mengakses fasilitas kesehatan. Responden yang memiliki kendaraan pribadi lebih banyak menggunakan fasilitas kesehatan dibandingkan dengan yang tidak memiliki kendaraan. Lokasi tempat tinggal juga memiliki hubungan yang signifikan dengan akses fasilitas kesehatan. Masyarakat yang tinggal diperkotaan mengakses fasilitas kesehatan yang lebih banyak dibanding masyarakat yang tinggal di desa (Davy et al., 2016). Ketersediaan alat transportasi memiliki pengaruh terhadap aksesibilitas ke fasilitas layanan kesehatan. Transportasi sangat penting bagi masyarakat untuk mengakses pelayanan kesehatan. Idealnya, akses masyarakat terhadap fasilitas kesehatan harus mudah sehingga masyarakat dapat memperoleh pelayanan kesehatan yang diinginkan. Jika biaya transportasi terlalu tinggi dapat mempengaruhi kualitas hidup masyarakat, karena sebagian kebutuhan hidup harus dialokasikan untuk akses transportasi. Semakin tinggi biaya transportasi, semakin sedikit akses masyarakat terhadap fasilitas kesehatan(Nainggolan et al., 2016).

Faktor persepsi masyarakat tentang kesehatan. Persepsi masyarakat terhadap kesehatan memiliki hubungan yang signifikan dengan pemanfaatan pelayanan kesehatan karena $\rho=0,042$. Pada kenyataannya di masyarakat banyak konsep sehat dan sakit yang tidak sesuai, bahkan bertentangan dengan konsep sehat dan sakit yang diberikan oleh pemberi pelayanan medis. Masyarakat dan penyedia layanan kesehatan (provider) cenderung memiliki pandangan yang berbeda tentang kesehatan dan penyakit. Pada dasarnya terdapat perbedaan persepsi antara konsep penyakit (disease) dengan nyeri (disease), dimana biasanya masyarakat terkena penyakit, tetapi tidak merasa sakit. Masyarakat hanya menganggap dirinya sakit ketika lemah dan tidak mampu melakukan aktivitasnya (Mujahidah, 2013).

Faktor kualitas pelayanan kesehatan. Terdapat hubungan kualitas pelayanan dengan minat kunjungan ulang di Klinik Umum Rumah Sakit Bhineka Bakti Husada Kota Tangerang 
Selatan. Apabila jasa dalam hal ini pelayanan yang dirasakan sesuai dengan diharapkan, maka kualitas pelayanan dipersepsikan baik dan memuaskan. Jika pelayanan yang diterima melampaui harapan pelanggan, maka kualitas pelayanan dipersepsikan sebagai kualitas yang ideal. Begitupula sebaliknya, dengan demikian baik tidaknya kualitas tergantung kemampuan pada penyedia pelayanan dalam memenuhi harapan pemakaiannya secara konsisten (Saeed et al, 2013)

Faktor pendidikan. Akses kesehatan memiliki hubungan yang signifikan dengan pendidikan. Tingkat pendidikan yang tinggi lebih banyak memanfaatkan pelayanan kesehatan sebesar $82,6 \%$. Tingkat pendidikan yang rendah mengakibatkan masyarakat cenderung tidak mengakses pelayanan kesehatan. Pendidikan masyarakat yang rendah cenderung menyebabkan pengetahuan yang rendah tentang pentingnya kesehatan. Mereka tidak memahami manfaat layanan kesehatan dan kondisi yang ada di pada dirinya yang membutuhkan akses ke layanan kesehatan. Masyarakat dengan pendidikan tinggi cenderung mengurangi penggunaan layanan kesehatan informal (dukun) dan meningkatkan penggunaan layanan kesehatan modern (dokter dan paramedis) (Napirah et al., 2016). Tingkat pendidikan berkaitan dengan kemampuan menyerap informasi dan mengenali gejala suatu penyakit sehingga seseorang memiliki keinginan untuk menggunakan pelayanan kesehatan dan berperan aktif dalam mengatasi masalah kesehatannya (Koné Péfoyo \& Wodchis, 2013). Tetapi penelitian yang dilakukan di Nigeria menunjukan pendidikan tidak mempengaruhi akses pelayanan kesehatan hal tersebut dikarenakan jarak yang harus ditempuh masyarakat untuk mencapai pelayanan kesehatan sangat jauh sehingga masyarakat lebih memilih untuk melakukan pengobatan sendiri dibandingkan mengakses pelayanan kesehatan.
Faktor pendapatan. Pendapatan memiliki hubungan yang signifikan dengan pemanfaatan pelayanan kesehatan, pendapatan keluarga yang rendah lebih banyak tidak memanfaatkan pelayanan kesehatan sebesar $72 \%$. Pendapatan keluarga yang tinggi lebih banyak memanfaatkan pelayanan kesehatan sebesar 89,5\%. Hal ini menunjukkan masyarakat dengan pendapatan keluarga yang tinggi akan mempengaruhi proses pengambilan keputusan dalam mencari pelayanan kesehatan yang lebih baik dalam rangka meningkatkan derajat kesehatannya. Menurut (Putro et al., 2017), kesulitan keuangan berpengaruh sebagai hambatan bagi masyarakat dalam melakukan akses ke fasilitas pelayanan kesehatan sesuai kebutuhan secara tepat waktu, termasuk bagi mereka dengan kondisi kesehatan kronis.

Faktor pengetahuan. Pengetahuan memiliki hubungan yang signifikan dengan kemampuan seseorang mengakses fasilitas kesehatan. Salah satu faktor yang berpengaruh terhadap pembentukan perilaku adalah pengetahuan, semakin tinggi pengetahuan dan pemahaman tentang pentingnya mengakses fasilitas kesehatan sebagai tempat untuk mencari pertolong kesehatannya maka semakin tinggi tingkat akses fasilitas kesehatan (Kurniati \& Sulastri, 2018). Namun pada penelitian (Karman et al., 2016), menunjukan bahwa pengetahuan tidak memiliki pengaruh dengan akses fasilitas kesehatan. Penelitian yang dilakukan (Karman et al., 2016), pada masyarakat pesisir di Desa Bungin Permai menunjukan masyarakat memiliki pengetahuan yang kurang dalam memanfaatkan pelayanan kesehatan karena kurangnya pengetahuan keluarga tentang pentingnya pemanfaatan pelayanan kesehatan serta kemampuan ekonomi keluarga yang tidak memungkinkan untuk memanfaatkannya. Hal tersebut dipengaruhi oleh mata pencaharian masyarakat di desa bungin permai yang mayoritas sebagai nelayan. Oleh karena itu, meskipun masyarakat memahami pentingnya menggunakan fasilitas 
kesehatan tetapi tidak didukung oleh pendapatan yang cukup dan akses transportasi umum yang sulit menyebabkan hal tersebut tidak tercapai.

\section{SIMPULAN}

Akses kesehatan dipengaruhi oleh faktor jenis kelamin, waktu tempuh, biaya transportasi, lokasi tempat tinggal, persepsi masyarakat tentang kesehatan, kualitas pelayanan, pendidikan, pendapatan.

\section{DAFTAR PUSTAKA}

Adam, V. Y., \& Awunor, N. S. (2014). Perceptions and factors affecting utilization of health services in a rural community in Southern Nigeria. Journal of Medicine and Biomedical Research, 13(2), 117-124.

Ambo, K., \& Syawal, S. (2016). Faktor-Faktor Yang Berhubungan Dengan Pemanfaatan Pelayanan Kesehatan Bagi Masyarakat Pesisir Di Desa Bungin Permai Kecamatan Tinanggea kabupaten Konawe Selatan Tahun 2016. 1-9.

Bahasa, B. P. dan P., K.P., \& K.R.I. (2016). Kamus Besar Bahasa Indonesia dalam Jaringan. https://kbbi.kemdikbud.go.id/.

Davy, C., Harfield, S., McArthur, A., Munn, Z., \& Brown, A. (2016). Access to primary health care services for Indigenous peoples: A framework synthesis. International Journal for Equity in Health, 15(1), 1-9. https://doi.org/10.1186/s12939-016-0450-5

Kementrian Kesehatan RI. (2013). Riset Kesehatan Dasar. In Jakarta: Balitbang Kemenkes RI (Vol. 7, Issue 5, pp. 803-809). Jakarta : Balitbang Kemenkes RI. https://doi.org/10.1517/13543784.7.5.803

Khatimah, H., Sundari, S., Candra, C., Al, S., Yogyakarta, I., \& Yogyakarta, D. I. (2019). Factors related to access to health services for Indigenous peoples in Jayapura Regency, Province of Papua in 2018. 9(2), 150-156.
Koné Péfoyo, A. J., \& Wodchis, W. P. (2013). Organizational performance impacting patient satisfaction in Ontario hospitals: A multilevel analysis. BMC Research Notes, 6(1). https://doi.org/10.1186/1756-0500-6509

Kurniati, D., \& Sulastri, N. (2018). Hubungan Pengetahuan, Pendidikan Dan Akses Ke Pelayanan Kesehatan Dengan Upaya Pencarian Pertolongan Infeksi Menular Seksual (IMS) Pada Wanita Pekerja Seksual (WPS) Di Desa Pasirsari Kabupaten Bekasi. XI(I), 313-320.

Laksono, A. . (2016). Health Care Accessibility (Aksesibilitas Pelayanan Kesehatan). Kanisius.

Leach, M., Wiese, M., Agnew, T., \& Thakkar, M. (2018). Health consumer and health provider preferences for an integrative healthcare service delivery model: A national cross-sectional study. International Journal of Clinical Practice, 72. https://doi.org/10.1111/ijcp.13204

Levesque, J.-F., Harris, M., \& Russell, G. (2013). Patient-centred access to health care. International Journal for Equity in Health, 12(18), 1-9.

Men, C., Meessen, B., Pelt, M. Van, Damme, W. Van, \& Lucas, H. (2012). "I Wish I Had AIDS": A qualitative study on access to health care services for HIV/AIDS and diabetic patients in Cambodia. Health, Culture and Society, 2(1), 22-39. https://doi.org/10.5195/hcs.2012.67

Mujahidah, M. Faktor Yang Berhubungan Dengan Perilaku Konsumen Dalam Pemanfaatan Pelayanan Kesehatan Di Puskesmas Marusu Kab. Maros Tahun 2013. Universitas Hasanudin.

Nainggolan, O., Hapsari, D., \& Indrawati, L. (2016). Pengaruh Akses ke Fasilitas Kesehatan terhadap Kelengkapan Imunisasi Baduta (Analisis Riskesdas 2013). Media Penelitian Dan Pengembangan Kesehatan, 26(1), 15-28. 
https://doi.org/10.22435/mpk.v26i1.4900.1 5-28

Napirah, M. R., Rahman, A., \& Tony, A. (2016). Faktor-Faktor Yang Berhubungan Dengan Pemanfaatan Pelayanan Kesehatan Di Wilayah Kerja Puskesmas Tambarana Kecamatan Poso Pesisir Utara Kabupaten Poso. Jurnal Pengembangan Kota, 4(1), 29. https://doi.org/10.14710/jpk.4.1.29-39

Putro, G., Roosihermiatie, B., Samad, A., (2017). Risearch Evaluation on Health Services of District Helath Ensurance in
Kutai Kertanegara District, East Kalimantan Province. Buletin Penelitian Sistem Kesehatan, 20(4), 165-174. http://ejournal2.litbang.kemkes.go.id/index. $\mathrm{php} / \mathrm{hsr} /$ article/view/84

Saeed BII, Abdul-Aziz AR, Z. X. (2013).

Assessing the influential factors on the use of healthcare : evidence from Ghana. International Journal of Business and Social Science, 4(1), 12-20. 